8. Топчий И. В. Проблема гармонии в западноевропейской культуре: автореф. дис. ... канд. филос. наук. Ростов-на-Дону, 2004. 28 с.

9. Шестакова Д. В. Музика і слово: діалог у п’єсі Антона Чехова «Три сестри» та в іiі інтерпретації в однойменній опері Петера Етвеша // Часопис Національної музичної академії України імені П. І. Чайковського. 2013. № 3.

\title{
References
}

1. Afonina O.S Artistic techniques of double coding in the "synthesis of arts." Actual problems of the history, theory and practice of artistic culture. №. 38. Kyiv: Millennium, 2017 [in Ukrainian].

2. Garmash Y. T., Pryadko O.M. Color harmony in works of screen painting. Actual problems of the history, theory and practice of artistic culture. №. 38. Kyiv: Millennium, 2017. [in Ukrainian].

3. Ivasyuk K. Transformation of the phenomenon of "synthesis of arts" in the course of historical development. URL: http://oldconf.neasmo.org.ua/node/519 [in Ukrainian].

4. Aesthetics: Educ. tool. (2003). MP Kolesnikov, OV Kolesnikov, VO Lozovoit, etc.; Edited VO Lozovy. Kyiv: Yurincom Inter. URL: /http://radnuk.info/pidrychnuku/estetika/497-kolesnikov/10254-s-3[in Ukrainian].

5. Kagan MS Art Morphology: A Historical-Theoretical Study of the Inner Structure of the Art World. Parts I, II, III. Leningrad: Art, 1972. [in Russian].

6. Rogotchenko O.O. Art synthesis in architectural form: from totalitarian to indifferent. Bulletin of the National Academy of Management Personnel of Culture and Arts. Kiev: IDEA-PRINT, 2019. № 1. [in Ukrainian].

7. Stanislavskaya K.I. (2016). Art and entertainment forms of modern culture: a monograph. Kyiv: NAKKKIM [in Ukrainian].

8. Topchiy I.V. (2004). The problem of harmony in Western European culture: author. diss. ... Cand. the philosopher. Sciences. Rostov-on-Don [in Russian].

9. Shestakova D.V. Music and the word: dialogue in Anton Chekhov's play "Three Sisters" and in its interpretation in Peter Etvesh's opera of the same name. Journal of the National Music Academy of Ukraine named after P.I. Tchaikovsky. 2013. № 3. [in Ukrainian].

Стаття надійшла до редакиії 18.09.2019

Прийнято до публікаиії 19.10.2019

УДК.012+(911.375.1:130.2)

\author{
Боголюбова Ірина Владиславівна \\ аспірантка Національної академії \\ керівних кадрів культури і мистецтв \\ ORCID 0000-0002-1154-122X \\ avena9@outlook.com
}

\section{УРБАНІСТИЧНА КУЛЬТУРОЛОГІЯ: ПОЧУТИ ОБРАЗ МІСТА (ЧАСТИНА II)}

Мета роботи полягає у встановленні кореляції міської фоносфери й бінарної системи розуміння образу міста. Визначенні особливостей фіксації, синтезу й трансформації звукового ландшафту конкретного образу в культурні практики, які формують абстрактний образ міста. Методологія дослідження. Полягає у застосуванні таких теоретичних й емпіричних методів як: інтерв'ю, що дозволить отримати інформацію щодо індивідуального сприйняття конкретного образу простору, специфіки фіксації міської фоносфери, а також іiі трансформації в культурні практики й таким чином репрезентації образів слухачеві авторами, контент яких аналізується; контент-аналіз проводиться з метою підбору творів за певною тематикою, аналіз яких дозволить виявити особливості інтерпретації інформації, закладеної у творах і закономірності репрезентації образу міського простору авторами; структурно-функціональний метод застосований для визначення взаємозв'язку конкретного-абстрактного, індивідуального-колективного як структурних елементів в системі інтерпретації образу міста через призму міського саундскейпу. Наукова новизна. В даній розробці вперше здійснено спробу визначити особливості співвідношення зафіксованих й трансформованих елементів міської фоносфери відповідно бінарної системи образу міста: колективне-індивідуальне, конкретне-абстрактне. Висновки. В даній статті зроблено перші важливі кроки в теоретично-емпіричному дослідженні спроможності функціонування системи класифікації феномену образу міста. Обгрунтовано можливість саундскейпу репрезентувати трансформаційні процеси в просторі через фіксацію звукового ландшафту. Визначено дійсність існування

(C) Боголюбова I. В., 2019 
індивідуального, колективного сприйняття і виникнення індивідуально-симетричних образів. Встановлена можливість існування форми первинно колективного сприйняття образу простору, його автентичності фіксації й репрезентації.

Ключові слова: місто, образ міста, міське середовище, саундскейп, філд-рекордінг, звуковий ландшафт, Чорнобильська зона відчуження.

Боголюбова Ирина Владиславовна, аспирантка Национальной академии руководящих кадров культуры и искусств

\section{Урбанистическая культурология: услышать образ города}

Цель работы лежит в определении корреляции городской фоносферы и бинарной системы понимания образа города: коллективное-индивидуальное, конкретное-абстрактное. Методология исследования. Основывается на следующих теоретических и эмпирических методах как: интервью, которое позволяет получить информацию касательно индивидуального восприятия конкретного образа пространства, специфики фиксации городской фоносферы, а также её трансформации в культурные практики и таким образом репрезентации образов слушателю авторами, контент которых анализируется; контент-анализ проводится с целью подбора произведений по определенной тематике, анализ которых позволяет определить особенности интерпретации информации, заложенной в произведениях и закономерности репрезентации образа городского пространства авторами; структурно-функциональный метод применяется для определения взаимосвязи конкретного-абстрактного, индивидуального-коллективного как структурных элементов в системе интерпретации образа города через призму городского саундскейпа. Научная новизна заключается в впервые проведенной попытке определения соотношения зафиксированных элементов городской фоносферы относительно бинарной системы образа города: коллективное-индивидуальное, конкретное-абстрактное. Выводы. В данной статье осуществлены первые важные шаги в теоретически-эмпирическом исследовании способности функционирования системы классификации феномена образа города. Обоснованно возможность саундскейпа репрезентировать трансформационные процессы в пространстве через фиксацию звукового ландшафта. Определена действительность существования индивидуального, коллективного восприятия и возникновения индивидуально-симметрических образов. Установлена возможность существования формы изначально коллективного восприятия образа, его аутентичности фиксации и репрезентации.

Ключевые слова: город, образ города, городское пространство, саундскейп, филд-рекординг, звуковой ландшафт, Чернобыльская зона отчуждения.

\section{Boholiubova Iryna, Graduate student, National Academy of Culture and Arts}

Urban Cultural Studies: Hearing the Image of the City

The purpose of the article is to establish the correlation between the urban phonosphere and the binary system of understanding the image of the city. Determination of features of fixation, synthesis and transformation of the sound landscape of a particular image into cultural practices that form an abstract image of the city. Methodology. It involves the application of theoretical and empirical methods such as: an interview that will provide information on the individual perception of a particular image of space, the specificity of fixation of the urban phonosphere, as well as its transformation into cultural practices and thus the representation of images by the authors of the content being analyzed; content analysis is carried out in order to select works on specific topics, the analysis of which will reveal the peculiarities of interpretation of the information contained in the works and patterns of representation of the urban space image by the authors; structural-functional method is used to determine the relationship of concrete-abstract, individualcollective as structural elements in the system of interpretation of the image of the city through the prism of urban soundscape. Scientific novelty. In this development, an attempt was made for the first time to determine the peculiarities of the correlation of the fixed and transformed elements of the urban phonosphere according to the binary system of the city image: collective-individual, concrete-abstract. Conclusions. In this article, the first important steps in the theoretical and empirical study of the functioning of the system of classification of the phenomenon of the image of the city are made. The soundscape capability to represent transformation processes in space through the fixation of the sound landscape is substantiated. The reality of the existence of individual, collective perception, and the emergence of individually-symmetrical images is determined. The possibility of the existence of a form of the primary collective perception of the image of space, its authenticity of fixation, and representation has been established.

Key words: city, city image, urban environment, soundscape, field record, sound landscape, Chornobyl Exclusion Zone.

В першій частині статті [1] було розглянуто концепцію саундскейпу як нового підходу до вивчення міського середовища. Започаткування даного напряму Реймондом Мюррейем Шейфером надало змогу дослідникам вперше почути місто, відкрити новий кут зору на проблематику міського середовища і його образу. Розглянуто досвід Великобританії у створенні звукових мап міст як методу конструювання даних навколишнього середовища. А також в розробці автором було вперше представлено бінарну систему розуміння образу міста як конкретного і абстрактного, колективного й індивідуального. 
Актуальність теми дослідження. Вже понад 40 років як міські дослідження вийшли за рамки візуального аспекту й успішно демонструють нові результати в сфері звукового ландшафту, відкриваючи проблемні зони в міських просторах і їх образах. Однак, що стосується української наукової думки, то дана тематика досі не вийшла на широкий загал, а за сучасних регресивних культурних, політичних і соціальних процесів навряд чи в найближче десятиріччя зможе подолати цей бар'єр. Тому, саундскейп як підхід до вивчення образу міста вже зараз має бути заручений підтримкою з боку науковців, митців й всіх небайдужих до міського простору.

Мета роботи полягає у встановленні кореляції міської фоносфери відповідно сформованої бінарної системи інтерпретації образу міста. Визначенні особливостей фіксації, синтезу й трансформації звукового ландшафту в культурні практики, які формують абстрактний образ міста. Встановленні особливостей, як митці та культурні діячі індивідуально сприймають образи і як вони їх репрезентують слухачеві.

Аналіз досліджень і публікацій. Виявлено, що провідними дослідниками саундскейпу світ визнав Р.М. Шейфера, Б. Труакса, Б. Девіса, Д. Ньюа. Також феномен саундскейпу досліджували К. Бредсол, Д. Калогіанні, В. Томас, М. Квінтон, І. МакГрегор, М. Рефат, Я. Ейсса, А. Карлайл, Дж.Л. Бенто-Коельйо, А. Лобо Соарес, А. Лоуренс, І. Екічі, Б. Сміт, Д. Трегубова, М.А. Чубукова, А. Возьянов, А. Рясов та ін. Серед них композитори А. Сарокін, Н. Черний, Д. Ладзес, Я. Кіркегаард, П. Кьюсак. За тематикою феномену образа міста працювали К. Лінч, О. Г. Трубіна, Ш. Зукін, А. Г. Борін, Д. І. Земляний, Ю. В. Лобанова, Ю. А. Кузовенкова, Л. Є. Трушина, Л.М. Набілкіна, Ю. В. Черкасова, С. С. Ляхова, М. Л. Паламарчук, Я. В. Верменич та ін.

Виклад основного матеріалу. В акустичній організації міського простору переважає антропофонія - звуки, що генеруються людською діяльністю. Дані проекту London Sound Survey [13], який фіксує звуковий ландшафт британської столиці, в якому було охоплено основні звукові категорії міста, демонструють, що антропогенний шум перевищує рівень біофонії щонайменше в три рази. Такі категорії як людський голос і музика за своїм агресивним характером впливу на слухача можуть бути сприйнятими як шум, від якого він намагатиметься захиститись, вдягаючи навушники й вмикаючи свою, персонально підібрану музику [7, 154]. «Радіоприймачі, «уолкмени» і «айподи» стали першими інструментами досягнення автономії, персональної свободи від перенасиченого шумом навколишнього середовища: за допомогою музики й аудіокниг, виходячи 3 власних пріоритетів, ми вибудовуємо власний «приватний» світ - емоційно насичений, психологічно комфортний і безпечний» $[7,154]$.

Олександр Сарна формує думку, що основна аудиторія вжитку продуктів радіомовлення автомобілісти, які користуються такою перевагою радо як «фоновість». Безліч музики, як частина фоносфери, а також вільний доступ до неї, призводить до обезцінювання та зникнення культури іiі споживання [7, 155]. Звідси слідує, музика перетворюється в своєрідну форму шумового забруднення, в якому твори мистецтва губляться серед буденного фону, який дратує, - запевняє О. Сарна. Культуролог, філософ Герберт Маршал МакЛюен, яким захоплювався Р. Шейфер, розкрив проблематику звукового ландшафту з культурологічної точки зору. Справа в тому, що розвиток цифрових технологій протягом XX століття повертає слух до процесу культурного формування, на відміну від попередніх епох культури читання й письма, де в своїй основі задіяно зір. Поліфонія міста - джерело антропологічних даних. Воно розповідає про культурні вподобання містян, їх соціальне життя, настрій тощо [8].

Дратівливий буденний фон в 1960-1970-х роках став предметом зацікавленості композиторів і дослідників. Серед них було виділено три основні групи, які задіяли концепцію саундскейпу: ті, хто поставили для себе в пріоритеті акустичну екологію; ті, хто урівнювали звуки, не поділяючи їх на hifi (якісні) i lo-fi (неякісні), а вважали, що справа лише в акустичній грамотності; а також ті, котрі фіксували звук й трансформували його в музичні композиції. Сам же винахідник саундскейпу, енвайронменталіст Р. Шейфер був і акустичним екологом, і навчав акустичної грамотності своїх студентів. В його посібнику «A Sound Education» [14] сформовано специфічні завдання на вслуховування звуків міського середовища, музики міста. А окрім того, навіть серед авторських музичних композицій Р. Шейфера існують такі, що присвячені тематиці неврозів містян XX століття. Так чи інакше, здебільшого він спрямував свої зусилля на вивчення саундскейпу міста. Музика міста, із середини 1990-х років, розглядається як концептуальна й символічна практика, що через призму бінарності колективного й індивідуального здатна конструювати образ певної місцини.

Подальший хід міркувань базується на значущості саундскейпу як підходу вивчення образу міста в сфері урбаністичної культурології. На це вказують проведений в даній розробці контентаналіз матеріалу, створеного безпосередньо на основі філд-рекордінгу. Досліджуваний контент має 
свою специфіку, оскільки «народжений» через призму техногенної катастрофи 1986 року, яка дала збій в культурних й соціальних процесах України. Матеріал обраний в рамках такого концепту не випадково. Трансформаційні процеси в часі й просторі, які утворила за собою катастрофа охоплюють як колективне, так й індивідуальне сприйняття й інтерпретацію, емоційну пам'ять тощо. Результати дослідження цього явища надають широкий спектр можливостей вивчити особливості сприйняття $\mathrm{i}$ відображення образів поселень, що опинились в Чорнобильській зоні відчуження.

Спільнота пам'яті Чорнобиля, як одна зі складових колективної пам'яті, що наприкінці XX століття була на піку суспільного дискурсу, на сьогодні відтіснена на периферію. Олексій Браточкін роз'яснює: «Якщо згадати, які пам'ятники збудовано, або ж як згадують в сьогоденні Чорнобиль, достатньо проаналізувати останню виставку в музеї до 25-річчя аварії. На початку експозиції висять чорно-білі фотокартки катастрофи, а 90\% їх показує, що все вже подолано» [3]. Однією 3 причин занепаду історичної пам'яті історик називає відсутність роботи з травматичним історичним досвідом. О. Браточкін оперує терміном «культурна травма» щодо усвідомлення наслідків для суспільства подій, які «приміряли» на себе це визначення [3]. Сьогодні ми вже наштовхуємось на зовсім іншу реальність. Виявляється, ця певна спільнота не змогла настояти на тому, щоб їх пам'ять змогла отримати «достойне оформлення».

За останнє десятиліття серед культурних і мистецьких діячів зросла кількість культурних практик інтерпретації образу міст або поселень Чорнобильської зони відчуження. Значний інтерес до звукових ландшафтів вищезазначених об'єктів помічено серед білоруських, німецьких, англійських, чеських митців. На відміну від «живих» міст, вивчення образу відселених пунктів має цілу систему взаємодій суб'єкта (звуковий ландшафт) й об'єкта (образ поселення), митця і слухача. Такі культурні практики призводять до зміни і особистості, і суспільства [2]. Як стверджує доктор філософських наук В. П. Большаков - подібна практика розуміється як діяльність або поведінка людини в безпосередньому освоєнні дійсності, в тому числі самого себе: породження, реалізація, збереження й репрезентація досвіду і навичок такого освоєння. А їх виникнення відбувається в період становлення культури в цілому [2]. Культурна травма трансформує паттерни мислення й усвідомлення людини, суспільства. Можна стверджувати, дослідники звукового ландшафту за допомогою саундскейпу створюють сучасну культуру репрезентації образів поселень Зони відчуження для молодого покоління $з$ метою конструювання в свідомості й самих образів поселень, розуміння дійсності, необачних наслідків суспільства, формування нового мислення і ставлення до природнього простору в цілому.

Аналіз плеяди творців саундскейпу, що працювали в Чорнобильській зоні відчуження варто розпочати 3 неповторної цитати, яка лаконічно, але грунтовно віддзеркалює сутність подібних культурних практик. «Ми формуємо звуковий ландшафт своїм відношенням до природи», - мотивує англійський саунд-журналіст Пітер Кьюсак. Натхненний місцями, де присутній яскраво виражений синтез урбанізації і природи, сьогодні свої дослідження П. Кьюсак називає «портрети міст» [10]. Він вважає, чорнобильські міста можуть бути як аудіально, так і візуально привабливими, красивими й атмосферними. Часто існує крайня дихотомія між естетичною реакцією і знанням «небезпеки», будь то забруднення навколишнього середовища, соціальна несправедливість, військова або геополітична ситуація [10].

«Звуки небезпечних місць» — проект до якого входять звукові ландшафти чорнобильських поселень. «Першим звуком, який мені вдалося записати в Чорнобилі, було потріскування високовольтної лінії. Я був дуже здивований, тому що думав, що ця лінія «мертва». Виявилося, що по ній йде струм: тільки не від відключеної атомної електростанції, а до неї, так як на території Чорнобиля працюють ще кілька тисяч чоловік, їм потрібна електроенергія» [10]. В даному випадку відбувається трансформація в свідомості митця, вивільнення від нав'язаних суспільством паттернів щодо цілісного розуміння образу Зони відчуження. Теоретично більша доля суспільства знає, Зона відчуження ЧАЕС - бездиханна територія.

Відомо, поліські міста оточені надзвичайною кількістю природних ландшафтів. Саме цьому явищу наступним етапом П. Кьюсак приділив увагу. Наприклад, запис різноманітності пташиних голосів навколо Чорнобиля додає «життєвості» місту, оскільки за десятиліття після атомної катастрофи багатоманітність фауни повернулась на «мертві» терени [10]. Загалом остаточно скомпонований проект утворив образ поселень через звукозаписи різнобарвної роботи, електрики та радіометрів; покинутого міста Прип'ять; сіл, в яких мешкають самосели; багата жива природа Чорнобиля; вірші та пісні чорнобильців [10]. Однак, проект саунд-журналіста створив достеменний «портрет живого міста», завдяки зафіксованому звуковому ландшафту й ретрансльованому від митця до слухача. 
Серед композицій саунд-арт-художника Антона Сарокіна $є$ експеримент 3 історичною пам'яттю, репрезентованої через призму звукового мистецтва — «Pripjat'» [9]. Першопочатково композиція була створена й увійшла як саундтрек для документального фільму «Навколо Білорусі на велосипедах з моторами» - зворушливої документальної історії про пошук себе і свого коріння [6]. Кінострічка зав'язується на сюжеті, як два молодики експериментуючи 3 «традиціями батьків» власноруч, на базі вітчизняних велосипедів «Аїст», встановлюють китайські мотори й вирушають в подорож паралельно кордону Білорусі - понад три тисячі кілометрів. Головна ідея, якою пронизаний фільм - прагнення пізнати архаїчність природного середовища й зафільмувати 20 -літню культуру, яка, на думку авторів, вже починає зникати [6]. Платівка, що зберігає в собі музичний супровід кінострічки сама по собі виступає тим самим кінцевим результатом саундскейпу і: «...звучить як сильний, драматично вивірений музичний тріп по безкрайніх просторах і незліченних вимірах того, що ми називаємо Батьківщиною і того, що ми при цьому відчуваємо» [6], — тобто образи навколишнього середовища країни.

Під час аналізу музичного твору А. Сарокіна, базуючись на матеріалах інтерв'ю автора даної статті з автором композиції, було відмічено черговий факт того, що образ міста має дві основні фази сприйняття: індивідуальна й колективна. Розглянемо алгоритм про який саме йдеться. По-перше, назва композиції «Прип'ять», при умові, що слухач знав іiі заздалегідь до прослуховування, може стати тригером, який викликає недостеменний паттерн мислення відносно реальності. Загалом такі явища, як поліська культура і Зона відчуження більшою мірою — паттерн мислення із базових складових, як звук потріскування дозиметра, покинуті домівки й дитячі іграшки, атомна станція, що в подальшому створює ідентичний колективний зміст образу середовища. При прослуховуванні композиції синтез її емоційної складової із, так би мовити, етнографічним семплом звучання голосу жительки (родички автору композиції) села Калинковичі Мозирського району поблизу ріки Прип’ять, яка веде розповідь про прадіда, формують образ поставарійного поселення із його специфічною поліською культурою. Інакше кажучи, слухач, що не має особистого відношення до поліської культури і іï поставарійної історії, 3 більшою вірогідністю буде мати типове уявлення без особистісно-індивідуальної інтерпретації, яка б могла просочуватися й трансформуватися в індивідуальний абстрактний образ.

Автор композиції сам по собі не є тим автором, який описує конкретний образ поселення, він $\epsilon$ носієм індивідуальної версії образу (візуально-мисленнєвого процесу i емоціями 3 ними пов'язаними), який відображено у звукозапису, оскільки напряму історично пов'язаний із поліською культурою. Композитор коментує індивідуальний образ у своїй уяві так: «Історія надзвичайно проста: недалеко від ріки Прип’ять народилась моя бабуся. Голосовий семпл — iï. Вона розповідає про мого прадіда $<\ldots>$ Від цього семплу я і відштовхувався далі. <..> Моє трактування в більшій мірі пов'язане з особистими спогадами і тим часом, коли я був дитиною», - розкриває центральний контекст композиції художник в інтерв'ю.

Вище йшла мова про загальноприйняті поняття щодо уявлення поліської культури. Ось тут якраз може бути зафіксовано перехідну форму від індивідуального до колективного сприйняття, а саме індивідуально-симетричні образи [1]. А. Сарокін зазначає, в першу чергу композиція звучить про ріку Прип'ять і його дитинство на ії теренах. Разом з тим, автор даної статті має так само пряме відношення до поліської культури і іï травматичної історії через свої коріння із тепер вже Зони Відчуження. Заздалегідь розуміючи, про що саме йтиметься в звучанні композиції, при першому ж прослуховування на думку спадали образи доаварійного Полісся із його піщаними дюнами $\mathrm{i}$ низькорослими соснами, зафіксованими на чорно-білій фотоплівці на початку 1980-х років, господарськими традиціями, притаманних визначеному регіону. Одночасно в свідомості відбувалось порівняння тих самих доаварійних ландшафтних просторів на фотокартках із реаліями вже поставарійних ландшафтів з різницею в понад 30 років. В цілому підтекст композиції грунтувався на спільній історичній пам'яті. Одначе, А. Сарокін помітив певну різницю в сприйнятті й зазначив, що це в даному випадку на краще - нове читання образу. Звісно, пояснює він, що в композиції можна провести паралелі між часом/подіями до і після катастрофи. Проте це все ж більш через призму стороннього читання образу. Певним чином можна стверджувати про функціонування перехідної форми сприйняття від індивідуального до колективного, частково отримавши індивідуальносиметричні образи в контексті звучання композиції.

Чи може образ первинно звучати лише колективною формою сприйняття? Найглибшого класичного звучання конкретного простору втілив датський саунд-арт-художник Якоб Кіркегаард в проекті AION [12], спираючись на ідею основоположної праці американського композитора Елвіна Лусьєра «Я сиджу в кімнаті». Я. Кіркегаард здійснив спробу довести колективність сприйняття 
звучання образу методом Е. Лусьера, розробленим в 1969 році. Останній записавши звук свого голосу в кімнаті, в якій він сидів, надалі програвав цей запис, накладаючи його один на одний в цій же кімнаті. У такий спосіб резонансні частоти посилюються, виникає процес, що не дає записаним звуками злитися в один резонансний тон [5]. I такий запис - не компільована композиція із різних «мотивів». Це запис без будь якого оброблення (за виключенням накладання одного й того ж звуку один на одного). У випадку Я. Кіркегаарда даний метод став лише підсиленням непомітного для нашого вуха звучання простору. Відмінності в творах Я. Кіркегаарда від практики Е. Лусьєра полягають в тому, що: по-перше, на запису відсутній голос автора; ведеться виключно запис шумів в приміщенні. По-друге, автор на протязі всього запису був відсутній, так би мовити, «в полі зору» звукового ландшафту.

Задля створення образу міста Прип'ять було обрано три об'єкти: спортивний зал, аудиторія і басейн дитячої поліклініки. Четвертий об'єкт — дерев'яна церква в селі Красно, художник обрав для створення образу покинутих сіл [12]. Проект заслуговує носити ім'я, яке з грецької мови перекладається як «нескінченність» або «вічність», проміжок часу поза людським розумінням [12]. Спільною думкою задалися автор даної статті і Якоб Кіркегаард: чи містять простори сталу атмосферу минулих життів? Саме відчуття, що простір має почуття, стали першою мотивацією до фіксації конкретних образів поселень Зони відчуження, - надає роз'яснення композитор в особистому інтерв'ю. Тому Я. Кіркегаард вдався до специфічної фіксації конкретного образу, як чистий запис природнього ландшафту чотирьох різних місцевостей, шарів звуків цих просторів. Результат відповів на наше спільне запитання: «...я відчуваю, що спосіб, у який я записав звук, схожий на віддзеркалення, здавалося б, Ніщо. Через такий процес кожна кімната почала «співати» ...», - говорить художник. Вдалося не лише почути, а й зафіксувати сталу «вічність» поставарійної історії. Фіксація резонансу приміщень репрезентувала їх чисту сутність. Таким чином саундхудожник зміг передати автентичність звучання конкретного образу, не передбачаючи виникнення варіативності індивідуальних абстрактних образів.

Завершуючи дослідження образу міста через призму саундскейпу варто звернутися до відеопослання Девіда Ньюа під лаконічною, але змістовною назвою «Слухай» [11]. Певний час у стрічці звучить голос автора синтезуючись із трьома вищезгаданими категоріями саундскейпу: біофонія, геофонія, антропофонія. Кульмінація стрічки створює істинне розуміння методу звукового дослідження: композитор запитує, що ж буде, якщо зникне його голос, що тоді? I демонструє нам лист паперу із надписом «Слухай». Декілька останніх хвилин ми маємо змогу в тиші особисто осягнути зміст свого звукового ландшафту. «Вслуховуйся! I, вслуховуючись, думай про те, що ти можеш змінити» [11].

По завершенню варто сказати, в даній розробці зроблено перші важливі кроки в теоретичноемпіричному дослідженні спроможності функціонування бінарної системи класифікації феномену образу міста. Визначено можливість саундскейпу репрезентувати трансформаційні процеси в просторі через фіксацію звукового ландшафту. Обгрунтовано дійсність існування індивідуального, колективного сприйняття і виникнення індивідуально-симетричних образів. Встановлена можливість існування форми колективного сприйняття образу простору, його автентичності фіксації й репрезентації. Цікавий парадокс виявлено в тому, що кінцевий продукт, в результаті операцій зі саундскейпом, в культурних практиках може стати тією «персонально підібраною музикою», що й утворює звуконепроникний акустичний кокон [7, 154], в якому кожен з нас абстрагується від дратівливого міського звукового ландшафту.

\section{Лimepamypa}

1. Боголюбова Ірина Владиславівна. Урбаністична культурологія: почути образ міста (Частина I). Мистецтвознавчі записки. Київ, 2019. № 35. С. 83-89.

2. Большаков В П. Культурные практики эстетического и художественного освоения человеком мира. Вестник СПбГУКИ. Санкт-Петербург, 2017. № 1 (30). С. 36-39.

3. Браточкин А. Работа с прошлым в городском пространстве: специфика Беларуси. URL: http://eurocafe.by/lecture/2015/06/07/rabota-s-proshlym-v-gorodskom-prostranstve-specifika-belarusi. _ _ата звернення: 15.02.2019).

4. Буцко А. Музыка Чернобыля и звуки Берлина. DW. URL: https://tinyurl.com/ya8fn $7 \mathrm{hh}$ (дата звернення: 15.01.2019).

5. Лусьер Э. (2017). I am sitting in a room | Я сижу в комнате | ММДМ 4 октября 2017. Trajectory of Music URL: https://www.youtube.com/watch?v=hsoK2HILI_g (дата звернення: 26.01.2019).

6. Roman S. Фильм «Вокруг Беларуси на велосипедах с моторами». Ulej. URL:

https://ulej.by/project?id=78105 (дата звернення: 20.01.2019). 